\title{
The HIV-1 protective -35SNP effect in Caucasians is CD8 T cell mediated
}

\author{
T Corrah ${ }^{1 *}$, S Brackenridge ${ }^{2}$, N Goonetilleke ${ }^{2}$, H Yang ${ }^{2}$, S Deeks ${ }^{3}$, L Dorrell ${ }^{2}$, M Cohen ${ }^{4}$, A McMichael ${ }^{2}$ \\ From AIDS Vaccine 2012 \\ Boston, MA, USA. 9-12 September 2012
}

\section{Background}

Previous studies in Caucasians have observed that a single nucleotide polymorphism 35kb upstream of the HLA-C gene (-35SNP) associates with control of HIV-1 viral load set-point and cell surface expression of HLA-C. HIV-1 selectively downregulates HLA-A and HLA-B but not HLA-C, via the action of the Nef protein. Thus it has been speculated that higher cell surface HLA-C expression results in a stronger HLA-C-restricted $\mathrm{T}$ cell response which might play a role in the control of HIV-1 replication in individuals with the protective $-35 \mathrm{C}$ variant. However, HLA-C-restricted CD8 $\mathrm{T}$ cell responses are relatively weak and we could find no difference in functional HLA-Crestricted CD8 $\mathrm{T}$ cell activity measured by IFN- $\gamma$ ELISPOT assay, according to -35SNP genotype. Therefore, we aimed to examine if there is any correlation between total CD8 $\mathrm{T}$ cell function and the -35SNP.

\section{Methods}

The viral suppression assay, which involves directly infecting autologous CD4 T cells with primary HIV-1 strains and co-culturing with autologous CD8 T cells, was used as a surrogate for immune control in vivo. The CD8 T cells from 46 antiretroviral therapy naïve HIV-1 infected Caucasians were assessed using this assay.

\section{Results}

When CD8 T cell antiviral activity was grouped according to -35SNP genotype, the -35CC group possessed significantly higher CD8 $\mathrm{T}$ cell antiviral activity than the -35TT group ( $\mathrm{p}=0.0151$; Mann-Whitney). Protective HLA-B alleles were always in linkage disequilibrium with HLA-C alleles that are in linkage disequilibrium with the $-35 \mathrm{C}$ allele. Similarly risk HLA-B alleles were in linkage

${ }^{1}$ Addenbrooks Hospital, University of Cambridge, Cambridge, UK

Full list of author information is available at the end of the article disequilibrium with HLA-C alleles that are in linkage disequilibrium with the $-35 \mathrm{~T}$ allele.

\section{Conclusion}

In conclusion, the protective -35SNP effect in HIV-1 disease is mediated through CD8 T cells. However, the -35SNP may simply be a marker for protective and risk HLA-B alleles.

\section{Author details}

'Addenbrooks Hospital, University of Cambridge, Cambridge, UK. ${ }^{2}$ Weatherall Institute of Molecular Medicine, University of Oxford, Oxford, UK. ${ }^{3}$ University of California San Francisco, San Francisco, CA, USA. ${ }^{4}$ University of North Carolina School of Medicine, NC, USA.

Published: 13 September 2012

doi:10.1186/1742-4690-9-S2-P28

Cite this article as: Corrah et al:: The HIV-1 protective -35SNP effect in Caucasians is CD8 T cell mediated. Retrovirology 2012 9(Suppl 2):P281.

Submit your next manuscript to BioMed Central and take full advantage of:

- Convenient online submission

- Thorough peer review

- No space constraints or color figure charges

- Immediate publication on acceptance

- Inclusion in PubMed, CAS, Scopus and Google Scholar

- Research which is freely available for redistribution
C Biomed Central

( 2012 Corrah et al; licensee BioMed Central Ltd. This is an Open Access article distributed under the terms of the Creative Commons Attribution License (http://creativecommons.org/licenses/by/2.0), which permits unrestricted use, distribution, and reproduction in any medium, provided the original work is properly cited. 